\title{
Cloning, expression and characterization of SeM protein of Streptococcus equi subsp. equi and evaluation of its use as antigen in an indirect ELISA
}

\author{
[Clonagem, expressão e caracterização de proteína SeM de Streptococcus equi subsp. equi $e$ \\ avaliação de sua utilização como antígeno em um ELISA indireto] \\ C.M. Moraes ${ }^{1}$, F.R. Conceição ${ }^{2}$, A.S.R. Rocha ${ }^{2}$, A.G. Santos Júnior ${ }^{2}$, L.M. Ribas ${ }^{2}$, \\ A.P.C. Vargas $^{3}$, C.E.W. Nogueira ${ }^{2}$, C. Gil-Turnes ${ }^{2}$, F.P.L. Leite ${ }^{2 *}$ \\ ${ }^{1}$ Faculdade de Medicina Veterinária e PPGSAAM - Universidade Federal do Pará - Castanhal, PA \\ ${ }^{2}$ Faculdade de Medicina Veterinária - Universidade Federal de Pelotas - Pelotas, RS \\ ${ }^{3}$ Centro de Ciências Agrárias - Universidade Federal de Santa Maria - Santa Maria, RS
}

\begin{abstract}
Strangles is an economically important horse disease caused by Streptococcus equi subsp. equi. The diagnosis can be confirmed either directly by bacterial isolation and PCR or by ELISA, which is an indirect method based on the detection of serum antibodies. The aim of this study was to clone, express and characterize the SeM protein of Streptococcus equi subsp. equi, evaluate its use as antigen in indirect ELISA and determine its performance to distinguish sera of negative, vaccinated and positive animals. This was initially performed by cloning the gene encoding the SeM protein and its expression in Escherichia coli. Subsequently, the protein produced was characterized and used as antigen in ELISA. Serum samples for evaluation were taken from 40 negative foals, 46 horses vaccinated with a commercial vaccine against strangles and 46 horses diagnosed with the disease. The test showed high specificity and sensitivity, allowing discrimination between negative and positive, positive and vaccinated animals, and vaccinated animals and negative sera. Thus, it was concluded that the protein produced rSeM, which can be used as antigen for disease diagnosis, and the described ELISA might be helpful to evaluate the immune status of the herd.
\end{abstract}

Keywords: Strangles, Streptococcus equi, SeM; ELISA

\section{RESUMO}

A adenite equina é uma enfermidade economicamente importante de equinos, causada por Streptococcus equi subsp. equi. Seu diagnóstico pode ser confirmado de forma direta, por meio de isolamento bacteriano e de PCR, ou de forma indireta, por meio de ELISA, método baseado na detecção de anticorpos séricos. O objetivo deste estudo foi clonar, expressar e caracterizar a proteína SeM de Streptococcus equi subsp. equi, avaliar sua utilização como antígeno em um ELISA indireto e determinar a capacidade do teste de distinguir soros de animais negativos, vacinados e positivos. Para tal, foi inicialmente realizada a clonagem do gene que codifica para a proteína SeM e sua expressão em Escherichia coli. Posteriormente, a proteína produzida foi caracterizada e utilizada como antígeno em um teste de ELISA indireto. Para avaliação do teste, foram utilizadas amostras de soro de 40 potros negativos, de 46 equinos vacinados com uma vacina comercial contra adenite equina e de 46 equinos com diagnóstico da doença. O teste demonstrou alta sensibilidade e especificidade, permitindo discriminar entre soros negativos e positivos, positivos e de animais vacinados, e negativos e de animais vacinados. Assim, conclui-se que a proteína rSeM produzida pode ser usada como antígeno para o diagnóstico da enfermidade e que o ELISA descrito pode ser útil para avaliar o estado imunológico do rebanho.

Palavras-chave: adenite equina, Streptococcus equi; SeM; ELISA

Recebido em 2 de agosto de 2012

Aceito em 12 de dezembro de 2013

*Autor para correspondência (corresponding author)

E-mail: fabio_leite@ufpel.edu.br 


\section{INTRODUCTION}

Strangles is a highly contagious and economically important infection in horses caused by Streptococcus equi subsp. equi ( $S$. equi), a Gram-positive Streptococcus belonging to Lancefield group C (Harrington et al., 2002; Waller and Jolley, 2007). The disease occurs with high morbidity and low mortality rates, and its economic impact is due to veterinarian expenses and the need to restrain animals from their activities (Newton et al., 1997). Efficient identification and treatment of carriers is important for prevention and eradication of this disease (Boyle, 2011).

Presumptive diagnosis is readily accomplished by using the clinical signs; however, the gold standard for definitive diagnosis is a bacterial culture (Sweeney et al., 2005). The diagnosis based on the isolation and identification of $S$. equi subsp. equi and the differentiation amongst the subspecies is traditionally based on biochemical tests (Kuwamoto et al., 2001). Nevertheless, one needs to be aware that strains with atypical patterns of fermentation of trehalose, lactose or both might be isolated (Grant et al., 1993).

Another method is through polymerase chain reaction (PCR), although PCR being more sensitive than bacterial culture, does not distinguish living from dead organisms. Thus, its use should be together with bacterial culture (Timoney, 2004). Since antibodies against the pathogen rise during the infection (Timoney, 2004; Robinson et al., 2013), ELISA (Enzyme Linked Immuno Sorbent Assay) is a Strangles diagnostic alternative. The use of ELISA for indirect diagnosis of the disease has become a subject of interest for researchers who wish to use the test as an auxiliary tool of equine adenitis control. (Knowles et al.,2010; Knowles, 2011).

S. equi synthesizes an outer membrane protein of $58 \mathrm{kDa}$ encoded by the $S e M$ gene that is particularly important due to its antiphagocytic and adherence properties. This protein has been used as a vaccine and diagnostic antigen for strangles (Timoney et al, 1997; Anzai et al., 1999; Harrington et al., 2002; Lindahl et al., 2011).
Brazil has the fourth largest herd of horses in the world, and Rio Grande do Sul state has the third largest squad in the country, with more than 452,000 heads (IBGE, 2009). For this reason studies to assist in the epidemiological investigation and diagnosis of important diseases for this animal species are extremely relevant.

The aim of this study focused on cloning, expressing and characterizing the recombinant SeM protein of $S$. equi subsp. equi and evaluating it as antigen in an indirect ELISA.

\section{MATERIAL AND METHODS}

For the execution of this work the serum samples were collected in the South of Brazil, in Rio Grande do Sul State. Peripheral blood, collected from different farms, was drawn using a $19 \mathrm{~g}$ needle attached to Vacutainer tubes (BectonDickinson, Rutherford, NJ) from the jugular vein of 40 colostrum deprived foals (negative control), from 46 horses vaccinated with commercially available vaccine against strangles, and also from 46 horses with clinical and etiological diagnosis of strangles (positives). The presence of carrier animals in different groups was not considered in this work. The vaccinated animals received three intramuscular doses of $5 \mathrm{~mL}$ of commercial vaccine (bacterin adjuvanted with alumen hydroxide), (Vacina contra garrotilho Leivas Leite S/A Indústrias Químicas e Biológicas), with the first dose given 180 days after birth, the second 21 days later, and the third 30 days after the second. The clinical diagnosis of the disease was based on clinical signs, and etiology was confirmed by bacterial isolation and biochemical confirmation using the commercial kit API 20 STREP (BioMerieux, France). The same methodology was used to isolate and characterize the field used to clone the recombinant protein. Sera samples were stored at $-20^{\circ} \mathrm{C}$ until usage.

The bacterial strain used to extract DNA to be used as a template for rSEM was a field strain isolated and characterized previously. It was grown in Brain Heart Infusion (Difco, USA), enriched with $2 \%$ Peptone (Difco, USA), and incubated at $37^{\circ} \mathrm{C}$ overnight. Genomic DNA was extracted, according to Sambrook and Russel (2001), using cetyltrimethylammonium bromide (CTAB) protocol after treatment with $5 \mu \mathrm{L}$ of proteinase $\mathrm{K}(20 \mathrm{mg} / \mathrm{mL})$ for $60 \mathrm{~min}$ at $37^{\circ} \mathrm{C}$. The 
nucleic acid was extracted with buffered phenolchloroform and precipitated with isopropanol and ethanol 70GL. Escherichia coli Top10F and BL21 (DE3) pLysS strains (Invitrogen ${ }^{\mathrm{TM}}$, USA) were used, respectively, for cloning procedures and expression of the recombinant protein.

Primers for $\mathrm{SeM}$ amplification (Primer forward: 5'CGGGATCCTCGAGGTTAGTCGTAC3'; primer reverse: 5'GGGGTACCTTAGTTTTCTTTGCGT3') were designed based on GenBank ${ }^{\mathrm{TM}} \mathrm{SeM}$ of $S$. equi subsp. equi sequence (access number U73162), using the Vector NTI 8.0 software (Informax ${ }^{\circledR}$, USA). The amplicon was purified using Ilustra ${ }^{\mathrm{TM}}$ DNA and Gel Band Purification kit (GE Healthcare, USA) and, after restriction digestion and ligation into pAE vector (Ramos et al., 2004), the ligation product was used to transform by electroporation Escherichia coli Top10F (Invitrogen ${ }^{\mathrm{TM}}$, USA). All cloning procedures were carried out according to standard procedures (Sambrook and Russel, 2001). The recombinant plasmid, named $\mathrm{pAE} / \mathrm{Se} M$, was verified by sequencing of the entire insert with an automated DNA sequencer (MegaBACE 500, GE Healthcare, USA). The expression of the recombinant protein by $E$. coli BL21 (DE3) pLysS (Invitrogen ${ }^{\mathrm{TM}}$, USA) was induced with $1 \mathrm{mM}$ Isopropyl- $\beta$-Dthiogalactopyranoside (IPTG - Sigma, USA) for $3 \mathrm{~h}$, once the absorbance at $600 \mathrm{~nm}$ reached 0.60.8 . Pellets of the culture were obtained by centrifugation at $10,000 \times g$ for $10 \mathrm{~min}$ at $4^{\circ} \mathrm{C}$, suspended in lysis buffer $(50 \mathrm{mM} \mathrm{NaH} 2 \mathrm{PO} 4$, $300 \mathrm{mM} \mathrm{NaCl}, 15 \mathrm{mM}$ Imidazole, $\mathrm{N}$-lauroylsarcosine $0.2 \%$ and $1 \mathrm{mg} / \mathrm{mL}$ of lysozyme), incubated at $4^{\circ} \mathrm{C}$ in an orbital shaker (CERTOMAT® BS-T, B. Braun Biotech International) for $30 \mathrm{~min}$ and sonicated. After centrifugation at $10,000 \times \mathrm{g}$ for $30 \mathrm{~min}$ at $4{ }^{\circ} \mathrm{C}$, the supernatant was purified by affinity chromatography in a nickel-charged Sepharose column using the ÄKTAprime chromatography system (GE Healthcare, UK) following the manufacturer's instructions. Fractions containing the recombinant protein were pooled and dialyzed in PBS containing $0.1 \%$ and without N-lauroylsarcosine $\mathrm{pH} 7.4$ for a $48 \mathrm{~h}$ period. The protein was quantified with the $\mathrm{BCA}^{\mathrm{TM}}$ Protein Assay Kit (Pierce, USA) following manufacturer's instructions.

Purified fractions of rSeM were separated in a $10 \%$ sodium dodecyl sulfate polyacrylamide gel electrophoresis (SDS-PAGE) resolving gel and dyed with Comassie blue following Sambrook and Russel (2001). Western blotting was done using $12 \mu \mathrm{L}$ of a solution containing $250 \mu \mathrm{g} / \mathrm{mL}$ of rSeM through transfer of SDS-PAGE to a nitrocellulose membrane (Hybond-C Extra, GE Healthcare, UK). The membrane was then blocked for $1 \mathrm{~h}$ with $5 \%$ non-fat dry milk, $1: 10,000$ anti- $6 \times$ His alkaline phosphatase conjugated monoclonal antibodies - MAb (Sigma, USA) was added and incubated for $1 \mathrm{~h}$. Then DAB-chromogen substrate $(9 \mathrm{~mL}$ Tris- $\mathrm{HCl}$ $50 \mathrm{mM}, 1 \mathrm{~mL}$ nickel sulphate $0.3 \%, 10 \mu \mathrm{L}$ of $30 \%$ hydrogen peroxide and $6 \mathrm{mg}$ 3.3diaminobenzidine tetrahydrochloride - Sigma, USA) was placed over the membrane and the reaction was recorded.

Dot blot was performed using rSeM and sera from horses clinically infected with $S$. equi diluted 1:2,000 in PBS-T. Ten $\mu \mathrm{L}$ of a solution containing $250 \mu \mathrm{g} / \mathrm{mL}$ of $\mathrm{rSeM}$ were applied on a nitrocellulose membrane (Hybond-C Extra, GE Healthcare, UK). The membrane was dried and then blocked with 5\% non-fat dry milk in PBS-T. After 3 washes the same amount of serum was placed over the antigen. After incubation for $1 \mathrm{~h}$, 1:10,000 peroxidase conjugated anti-horse $\mathrm{IgG}$ (whole molecule, Sigma, USA) was added and incubated for $1 \mathrm{~h}$. Anti- $6 \times$ His alkaline phosphatase conjugated MAb (Sigma, USA) was used as positive control and serum from colostrum deprived foals was used as negative control. The reaction was detected with DABchromogen substrate (Sigma, USA).

To standardize the ELISA test in order to determine the best serum dilution to be used, a check board was performed using different antigen concentration and sera dilutions (pool of sera from the day that supposedly would have the higher titer). Then the dilution that fell within the linear range of the ELISA was used. For detection of specific antibodies against $S$. equi, individual sera were tested in triplicate. The ELISA was standardized using polystyrene ELISA plates (CRAL, Brazil) sensitized at $4^{\circ} \mathrm{C}$ overnight with $50 \mu \mathrm{L}$ of $\mathrm{rSeM}$ containing $12 \mu \mathrm{g} / \mathrm{mL}$ suspended in carbonate-bicarbonate buffer $\mathrm{pH}$ 9.6. After this period the plates were washed 3 times with PBS-T and blocked using PBS-T with $5 \%$ non fat milk at $37^{\circ} \mathrm{C}$, for $1 \mathrm{~h}$. Sera of horses diluted 1:2000 were added in duplicate to the wells and incubated for $1.5 \mathrm{~h}$ at 
$37^{\circ} \mathrm{C}$. After 3 washes with PBS-T, 1:10.000 peroxidase conjugated anti-horse (whole molecule, Sigma, USA) was added and incubated for $1.5 \mathrm{~h}$ at $37^{\circ} \mathrm{C}$. Ortho-phenyl diamine was used as chromogen Optical densities (OD) were read at $492 \mathrm{~nm}$ in a MR 700 ELISA reader (Dynatech Labs. Inc., USA). A pool of sera from negative and positive animals was used in all plates, working as an intra-plate control.

The Receiver Operating Characteristics (ROC) analysis was used to estimate the specificity, sensitivity, cut-off, and the predictive values. The significance of the differences of mean absorbances was estimated by ANOVA, and the difference in means among the groups was estimated by the t-Test, using the Statistix software version 8 (Analytical Software, USA). The ROC analysis was performed by MedCalc statistical software, version 10.3.0.0., according to that described by Borsuk et al. (2011).

The study has approval from the Federal university of Pelotas Animal Ethic Committee under number CEEA 2133.

\section{RESULTS}

Sequencing of the cloned SeM gene showed $100 \%$ of identity with the GenBank ${ }^{\mathrm{TM}}$ sequences. The rSeM, with an apparent molecular mass of $58 \mathrm{kDa}$, was successfully produced by transformed $E$. coli BL21 (DE3) pLysS strains (Invitrogen $^{\mathrm{TM}}$, USA) and purified by affinity chromatography. The vector (pAE) used in this work has a histidine tail that served as tool for purification and detection of the recombinant protein.

The rSeM reacted in Western blots with anti$6 \times$ His alkaline phosphatase conjugated $\mathrm{MAb}$ (Figure 1A) and in dot blot with sera of horses with clinical and etiological strangles diagnosis (Figure 1B), showing that it has antigenic properties similar to native SeM.

The correlation between the groups assessed by ROC analysis with a cut-off OD value of 0.374 was able to discriminate the 46 positive animals from the 132 horses examined. Using this same OD cut-off value $(0.374)$ we could differentiate the vaccinated animals from the negative control ones. Using an ELISA OD threshold value of 0.374 to distinguish between positive and negative sera samples, this ELISA was able to yield a specificity of $100 \%$ and a sensitivity of $100 \%$ for this equine population. Using this same cut-off, and considering a population where the prevalence can range from 10 to $90 \%$, the test gives a positive predictive value of 82 to $99 \%$ and negative predictive value of $100 \%$, respectively, with the prevalence of the disease in a particular area (Figure 2).

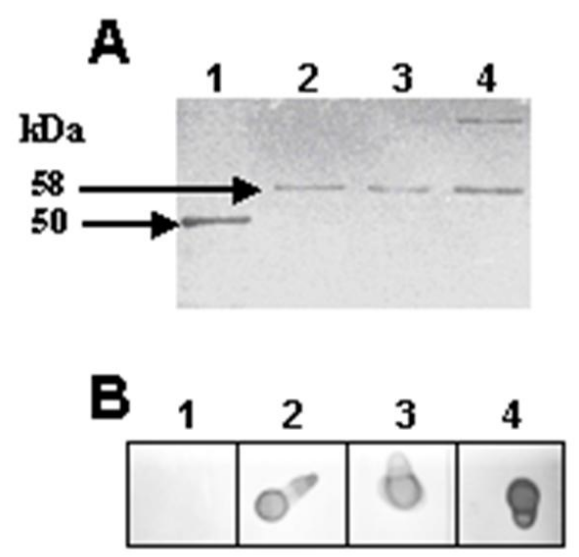

Figure 1. A- Western blot using rSeM and anti-6Xhis MAb. 1- Protein marker (50 kDa); 24, rSeM protein obtained during purification by affinity chromatography. B- Dot blot using rSeM. 1- negative control ( serum of colostrum deprived foal diluated 1:2.000); 2- positive control (anti-6×His alkaline phosphatase conjugated $\mathrm{MAb}$ ); 3-4- serum of horses with positive diagnosis of strangles, diluated 1:2.000.

Analyzing the vaccinated and negative control groups using the ELISA OD value of 0.374 as threshold we observed a sensitivity of $91.3 \%$ (79.2- 97.5) and a specificity of $100 \%$ (91.1100). Using this same value as a cut-off point and considering prevalence that can range from 10 to $90 \%$, it shows a positive predictive value of 80.2 to $99.6 \%$ respectively, and a negative predictive value that can range from 99 to $55 \%$ (Figure 2).

Considering a cut-off of 0.641 OD discriminates between the positive and the vaccinated animals, and observed a specificity of $89.1 \%$ and a sensitivity of $93.5 \%$. This test cut-off value gives a positive predictive value of $93.2 \%$ and a negative predictive value of $89.6 \%$ for a prevalence that can range from 10 to $90 \%$ in a specific area (Figure 2). 

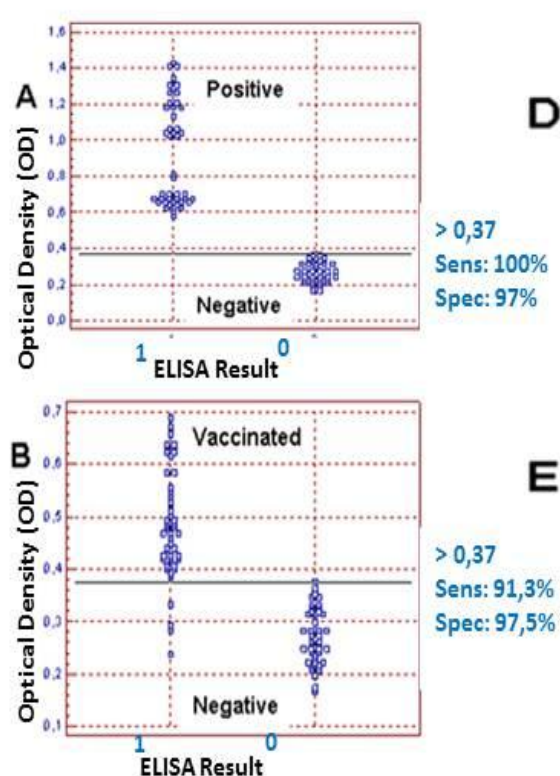

ELISAResult

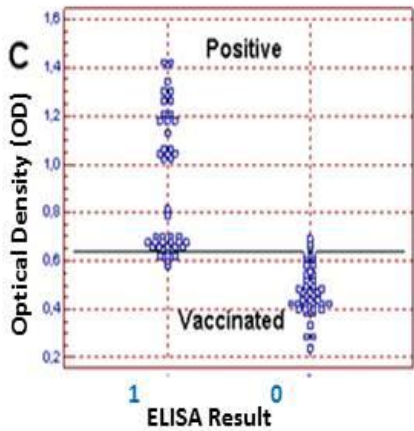

$>0,37$

Sens: $91,3 \%$ Spec: $97,5 \%$

E

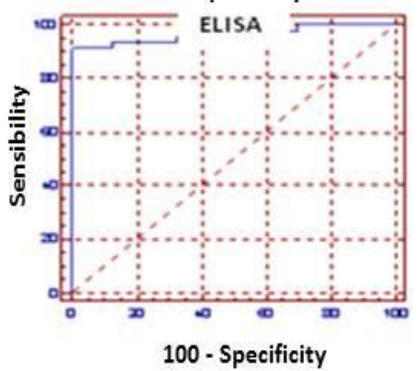

ELISA
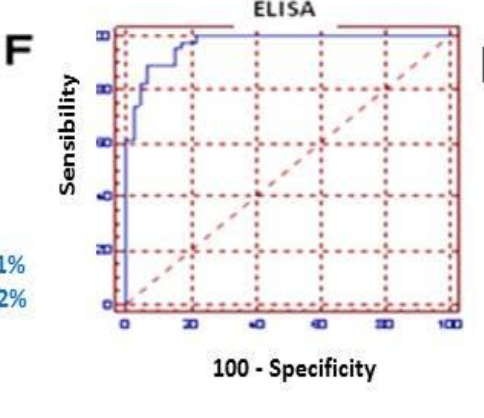

$>0,64$

Sens: $89,1 \%$ Spec: $93,2 \%$
Specifity/Sensibility

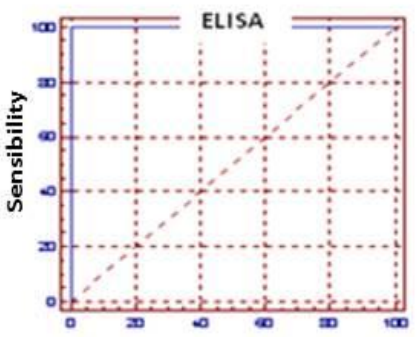

100 - Specificity

Predict values $+/-$
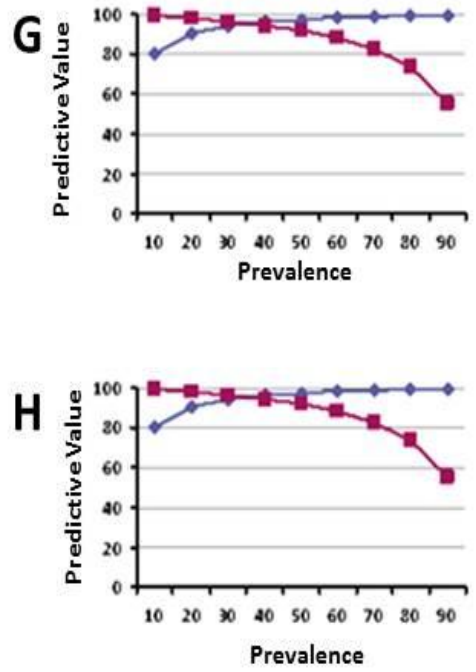

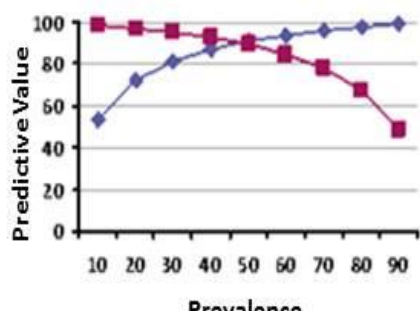

Prevalence

Figure 2. Receiver Operating Characteristic (ROC), analysis of the ELISA-rSeM using 46 positive, 40 negative and 46 vaccinated horse sera. (A) Frequency distribution of confirmed positive (1) and negative (0) sera. (B) Frequency distribution of confirmed vaccinated (1) and negative (0) sera. (C) Frequency distribution of confirmed positive (1) and vaccinated (0) sera. (D) ROC plot. Area under the curve $=1.000 ; 95 \%$ confidence interval between 0.958 and 1.000 (E) ROC plot. Area under the curve $=0.968$; 95\% confidence interval between 0.905 and 0.993. (F) ROC plot. Area under the curve $=0.971 ; 95 \%$ confidence interval between 0.912 and 0.994 . (Predicted values) Negative (squares) and positive (diamonds) predictive values associated with ELISA-rSMe for varying prevalence levels of strangle. Values were determined by ROC analysis based on ELISA OD mean value threshold. (G). Positive and Negative sera OD $\geq 0.347$, (H). Vaccinated and Negative sera OD $\geq 0.347$, (I) Positive and Vaccinated sera OD $\geq 0.642$.

\section{DISCUSSION}

Equine adenitis, also known as "Strangles" is currently considered the most often diagnosed infectious equine disease world-wide (Waller and Jolley, 2007). The disease has a low mortality rate, but high morbidity, which is highly significant where there are large concentrations of horses. In Brazil, the large number of animals coupled with the need for increased production leads to increased occurrence of this and other diseases and associated economic losses to the Equine (Silva and Vargas, 2006; Ribas et al., 2009). In the state of Rio Grande do Sul strangles outbreaks occur in various areas (Libardoni et al., 2013).

Since immunologically mediated protection against strangles resides in antibodies (Galan et al., 1986; Sheoran et al., 1997), ELISA is well suited to evaluate the immunity herd status for $S$. 
equi and for Strangles diagnosis (Robinson et al., 2013).

The ELISA method for the detection of serum antibodies against the SeM protein is commercially available, and can provide some information regarding the exposure of horses to S. equi (Waller and Jolley, 2007). This test, however, does not distinguish between vaccine and infection responses (Sweeney et al., 2005).

The results showed that rSeM of $S$. equi subsp. equi and the statisticals parameters defined to be used in ELISA were able to discriminate negative and positive, negative and vaccinated and vaccinated and strangles positive horses. These results are in accordance with the strong serum $\mathrm{IgG}$ responses to surface exposed proteins, including SeM, which is produced as a result of strangle infection (Timoney, 2004).

ELISA was subjected to Receiver Operating Characteristic analysis (Greiner, 2000), where this analysis has been successfully used for interpretation of ELISA results (Fosgate et al., 2007), including the Strangles diagnostics (Robinson et al., 2013). The rationale for the optimal ROC curve is that one wants the highest true-positive rate (sensitivity) for the lowest false positive rate (1-specificity).

It has been reported that the IgG isotypes in horses vaccinated and infected with $S$. equi are different. Vaccinated animals showed high levels of $\mathrm{IgGb}$ (IgG4 and $\mathrm{IgG7}$ ) in the serum, but not IgGa (IgG1), IgGc (IgG6) and IgG (T) (IgG3 and IgG5), while convalescent animals showed a high level of all isotypes (Sheoran et al., 1997, Lewis et al., 2008). Therefore, analysis of the data suggests that the difference in the isotype present in infected animals might be responsible for the OD difference observed when compared to vaccinated animals. However, the possibility would not be excluded that in convalescent horse the drop in titer with time might give confounding results. It is also possible to use the data from the ROC analysis cut-off to infer discrimination between the three groups, showing that ELISA is an effective tool to be used for monitoring and differentiating horse herds respiratory diseases.
Various diseases affect the respiratory tract of horses and depending on the presented clinical signs some of these diseases can be misinterpreted as Strangles, which can disrupt the diagnosis. Frey Junior (2006), reports that in the farms in southern Brazil the second group of diseases with higher occurrence in young horses are those associated with the respiratory tract. This fact demonstrates the importance of the ELISA assay described in this work, because the test can be an important tool to aid veterinarians.

The identification of antibodies against S.equi is important for determining the time of vaccination against the disease, as some animals may have complications related to deposition of antigen antibody complexes. Purpura hemorrhagica is a aseptic necrotizing vasculitis that can occur in horses after natural exposure or after vaccination of horses that have had strangles, which is related to high concentrations of serum antibodies against SeM protein (Sweeney et al ., 2005). For this reason, serological tests such as ELISA are indicated for monitoring horses that may be predisposed to this disease complication. (Boyle, 2011).

One of the main problems in the production of serological tests is the use of antigens that produce cross-reactivity with antibodies raised against different etiologic agents. Timoney et al. (1997) reported that proteins produced by some species of Streptococcus may high cross reactivity. The rSeM used in this paper is an antigen showing low cross reactivity with other proteins in the Streptococcus species, making the test presented here more efficient.

One limitation of this work is the number of animals studied. An increase in the number of sera tested may produce different results, therefore reducing the specificity and sensitivity observed. Nevertheless, the difference in absorbance between negative and positive animals by the ROC analyses is so distinct that the test will be very helpful for monitoring the immunological status of the herd. Since immunologically mediated protection against strangles predominantly resides in antibodies, information on the kinetics of protective immunity is of great importance, making the prophylactic measures easier to be conducted by the producer. 


\section{CONCLUSIONS}

The rSeM produced in this work suggests a promising antigen to use in the immune diagnostic of strangles. The ELISA method described in this study demonstrates sensitivity and specificity that allows discriminating a horse population into negative, vaccinated and positive for $S$. equi subsp. equi antibodies. This assay might constitute an important tool for monitoring herd immune status for strangles.

\section{ACKNOWLEDGEMENTS}

The PROPESP/UFPA, due to support for the publication of this paper.

\section{REFERENCES}

ANZAI, T.; TIMONEY, J.F.; KUWAMOTO, Y. et al. In vivo pathogenicity and resistance to phagocytosis of Streptococcus equi strains with different levels of capsule expression. Vet. Microbiol., v.67, p.277-286, 1999.

BORSUK, S.; ANDREOTTI, R.; LEITE, F.P. et al. Development of an indirect ELISA-NcSRS2 for detection of Neospora caninum antibodies in cattle. Vet. Parasitol. v.177, p.33-38, 2011.

BOYLE, A. Streptococcus equi subspecies equi infection (strangles) in horses. Compend. Contin. Educ. Vet., v.33, p.E1-7, 2011.

FOSGATE, G.T.; SCOTT, H.M.; JORDAN, E.R. Development of a method for Bayesian nonparametric ROC analyses with application to an ELISA for Johne's disease in dairy cattle. Prev. Vet. Med., v.81, p.178-193, 2007.

FREY JUNIOR, F. Índices epidemiológicos em potros Puro Sangue de Inglês, do nascimento ao sexto mês de vida, na região de Bagé-RS. 2006. 46f. Dissertação (Mestrado em Medicina Veterinária) - Curso de Pós-graduação em Veterinária, Universidade Federal de Pelotas.

GALAN J.E.; TIMONEY J.F.; LENGEMANN F.W. Passive transfer of mucosal antibody to Streptococcus equi in the foal. Infect. Immun., v.54, p.202-206, 1986.

GRANT, S.T.; EFSTRATION, A.; CHANTER, N. Laboratory diagnosis of strangles and the isolation of atypical Streptococcus equi. Vet. Record, v.133, p.215-216, 1993.
GREINER, M.; PFEIFFER, D.; SMITH, R.D. Principles and practical application of the receiver-operating characteristic analysis for diagnostic tests. Prev. Vet. Med., v.45, p.23-41, 2000 .

HARRINGTON， D.J; SUTCLIFFE， I.C.; CHANTER, N. The molecular basis of Streptococcus equi infection and disease. Microb. Infect., v.4, p.501-510, 2002.

IBGE-INSTITUTO BRASILEIRO DE GEOFGRAFIA E ESTATÍSTICA. Efetivo dos rebanhos por tipo de rebanho. 2009. Available in

http://seriesestatisticas.ibge.gov.br/series.aspx?vc odigo=PPM01. Acsses in: 7 nov 2013.

KNOWLES, E.J.; MAIR, T.S.; BUTCHER, N. et al. Use of a novel serological test for exposure to Streptococcus equi subspecies equi in hospitalised horses. Vet. Rec., v.166, p.294-297, 2010.

KNOWLES, E.J. Serological ELISA Test for Streptococcus equi (strangles). In: AHT / BEVA / DEFRA Equine Quarterly Disease Surveillance Report. v.7, p.1-2, 2011.

KUWAMOTO, Y.; ANZAY, T.; WADA, R. Microplate sugar-fermentation assay distinguishes Streptococcus equi from other streptococci of Lancefield's group C. Equi. Vet. Sci., v.2, p.47-49, 2001.

LIBARDONI, F.; VIELMO, A.; FARIAS, L. et al. Diversity of seM in Streptococcus equi subsp. equi isolated from strangles outbreaks. Vet. Microbiol., v.162, p.663-669, 2013.

LINDAHL, S.; SÖDERLUND, R.; FROSTH, S. et al. Tracing outbreaks of Streptococcus equi infection (strangles) in horses using sequence variation in the $s e M$ gene and pulsed-field gel electrophoresis. Vet. Microbiol., v.153, p.144149, 2011.

LEWIS, M.J.; WAGNER, B.; WOOF, J.M. The different effector function capabilities of the seven equine $\mathrm{IgG}$ subclasses have implications for vaccine strategies. Mol. Immunol., v.45, p.818-827, 2008.

NEWTON, J.R.; WOOD, J.L.; DUNN, K.A. et al. Naturally occurring persistent and asymptomatic infection of the guttural pouches of horses with Streptococcus equi. Vet. Rec., v.140, p.84-90, 1997. 
RAMOS, C.R.; ABREU, P.A.; NASCIMENTO, A.L.; HO, P.L. A high-copy T7 Escherichia coli expression vector for the production of recombinant proteins with a minimal $\mathrm{N}$-terminal His-tagged fusion peptide. Braz. J. Med. Biol. Res., v.37, p.1103-1109, 2004.

RIBAS, L.M.; MORAES, C.M; LINS, L.A. et al. Fatores de risco associados a doenças respiratórias em potros Puro Sangue Inglês do nascimento ao sexto mês de vida. Cienc. Rural, v.39, p.1789-1794, 2009.

ROBINSON, C.; STEWARD, K.F.; POTTS, N. et al. Combining two serological assays optimises sensitivity and specificity for the identification of Streptococcus equi subsp. equi exposure. The Vet. J., v.197, p.188-191, 2013.

SAMBROOK, J.; RUSSELL, D.W. Molecular cloning: a laboratory manual. 3. ed. New York: Cold Spring Harbor Laboratory Press, 2001. 800 p.

SHEORAN, A.S.; SPONSELLER, B.T.; HOLMES, M.A.; TIMONEY, J.F. Serum and mucosal antibody isotype responses to M-like protein (SeM) of Streptococcus equi in convalescent and vaccinated horses. Vet Immunol Immunopathol., v.59, p.239-251, 1997.
SILVA, M.S.; VARGAS, A.P.C. Adenite Equina: Aspectos clínicos, agente etiológico e métodos de diagnóstico. Arq. Inst. Biol., v.4, p.493-498, 2006.

SWEENEY, C.R.; TIMONEY, J.F.; NEWTON, J.R.; HINES, M.T. ACVIM Consensus Statement - Streptococcus equi infections in horses: Guidelines for treatment, control and prevention of Strangles. J. Vet. Int. Med., v.19, p.123-134, 2005.

TIMONEY, J.F. The pathogenic equine streptococci. Vet. Res. v.35, p.397-409, 2004.

TIMONEY, J.F.; ARTIUSHIN, S.C.; BOSCHWITZ, J.S. Comparison of the sequences and functions of Streptococcus equi M-like proteins SeM and SzPSe. Infect. Immun., v.65, p.3600-3605, 1997.

WALLER, A.S.; JOLLEY, A.K. Getting a grip on Strangles: Recent progress towards improved diagnostics and vaccines. Vet. J., v.173, p.492501, 2007. 